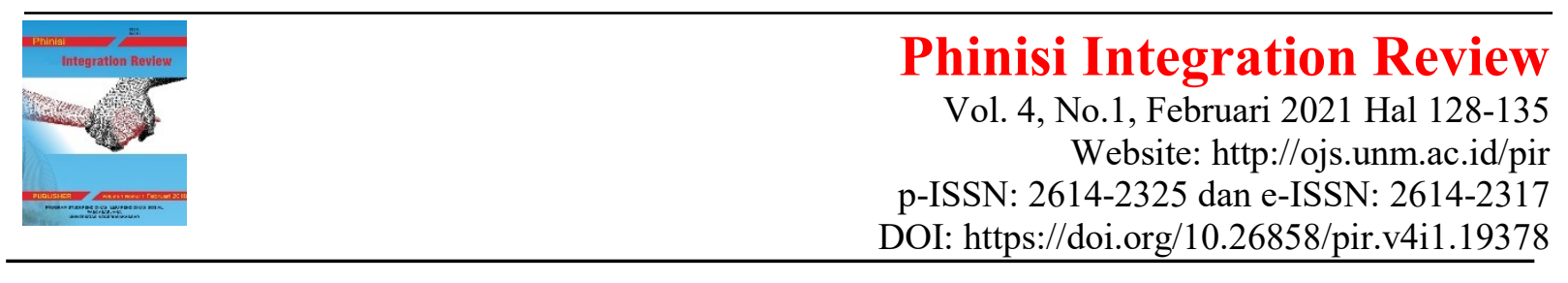

\title{
Kualitas Pelayanan Publik di Dinas Kependudukan dan Pencatatan Sipil Kabupaten Tolitoli
}

\author{
Masrin Gafar \\ Ilmu Administasi Negara, Universitas Madako Tolitoli \\ Email: masringafar95@gmail.com
}

\begin{abstract}
Abstrak. Penelitian ini bertujuan untuk mengetahui kualitas pelayanan publik di Dinas Kependudukan dan Pencatatan Sipil Kabupaten Tolitoli.Penelitian ini menggunakan jenis penelitian kualitatif. Teknik pengumpulan data dilakukan dengan observasi, wawancara dan dokumentasi. Informan dalam penelitian ini adalah pegawai Dinas Kependudukan dan Pencatatan Sipil Kabupaten Tolitoli dan masyarakat. Tehnik analisis data yang digunakan yaitu Pengumpulan Data, Reduksi Data, Penyajian Data dan Penarikan kesimpulan. Berdasarkan Dimensi bukti fisik (tangible) fasilitas pendukung layanan di Dinas Kependudukan dan Pencatatan Sipil Kabupaten Tolitoli belum memadai dan memuaskan masyarakat. hal ini dikarenakan kurangnya fasilitas yang di sediakan untuk perlengkapan penunjang pelayanan, Dimensi kehandalan (reliability) pegawai Dinas Kependudukan dan Pencatatan Sipil Kabupaten Tolitoli masih kurang handal dalam menyelesaikan produk layanan. Terkadang waktu yang ditentukan dalam menyelesaikan proses layanan tidak sesuai dengan batas waktu yang sudah ditetapkan, Dimensi daya tanggap (responsiviness) pegawai merespon halhal yang di tanyakan masyarakat dan memberi pengarahan terkait dengan pertanyaan tersebut, jaminan (assurance) berupa kemudahan layanan dan jaminan keamanan kepada masyarakat yang mengajukan permohonan layanan, empati (empaty) sikap petugas yang ramah dalam mengadapi permintaan, kritik, dan saran yang diberikan oleh masyarakat
\end{abstract}

Kata kunci: Kualitas layanan; dinas kependudukan; Pencatatan sipil; Dimensi; jaminan.

\begin{abstract}
This study aims to determine the quality of public services in the Department of Population and Civil Registration of Tolitoli Regency. This research uses qualitative research. Data collection techniques were carried out by observation, interviews and documentation. The informants in this study were employees of the Population and Civil Registration Service of Tolitoli Regency and the community. The data analysis techniques used were data collection, data reduction, data presentation and conclusion drawing. Based on the dimensions of physical evidence (tangible), service support facilities at the Department of Population and Civil Registration of Tolitoli Regency are inadequate and satisfying to the community. This is due to the lack of facilities provided for service support equipment, the dimension of reliability of the employees of the Department of Population and Civil Registration of Tolitoli Regency is still not reliable in completing service products. Sometimes the time specified in completing the service process is not in accordance with the predetermined time limit, the dimensions of employee responsiveness (responsiviness) of employees respond to things that are asked by the public and provide directions related to these questions, assurance (assurance) in the form of ease of service and security guarantees to people who apply for services, empathy (empaty) for the friendly attitude of officers in dealing with requests, criticism, and suggestions given by the community
\end{abstract}


Keywords: Quality of service; office of demographic affairs; Civil registration; Dimensions; guarantee.

\section{PENDAHULUAN}

Pelayanan publik ialah segala kegiatan yang dilaksanakan oleh suatu organisasi atau instansi sebagai upaya pemenuhan kebutuhan masyarakat. Pelayanan ini dilaksanakan sesuai dengan peraturan perundang-undangan dengan aturan pokok dan tatacara yang telah ditetapkan oleh tiap-tiap organisasi atau instansi.

Salah satu dari penyelenggara layanan publik ialah instansi pemerintahan. Bentuk layanan dari instansi pemerintah ini, diantaranya yaitu pada bidang Administrasi Kependudukan. Dalam Pasal 1 UU No. 24 Tahun 2013, Tentang Administrasi Kependudukan diartikan sebagai rangkaian penataan dan penertiban dokumen dan data Kependudukan melalui Pendaftaran Penduduk, Pencatatan Sipil, pengelolaan Administrasi Kependudukan, serta pendayagunaan hasilnya untuk pelayanan publik dan pembangunan sektor lain.

Sejak dikeluarkannya UU No. 22 Tahun 1999, Tentang Pemerintah Daerah. yang kemudian direvisi dengan UU No. 32 Tahun 2004, Pemerintahan Daerah secara terus menerus berupaya meningkatkan kualitas pelayanan publik. Dalam meningkatkan pelayanan publik pemerintah daerah diberikan keleluasaan untuk merancang dan menentukan sendiri jenis pelayanan yang dibutuhkan oleh masyarakat. dengan kebijakan ini, pemerintah daerah diharapkan mampu memberikan kualitas pelayanan prima kepada masyarakat setempat untuk mencapai kemakmuran dan kesejahteraan lokal.

Kualitas pelayanan prima yang dimaksud yaitu pelayanan yang mendekatkan pemerintah kepada masyarakat. Hal ini diwujudkan dengan cara mengetahui dan menganalisis berbagai persoalan yang dihadapi oleh masyarakat, untuk kemudian menciptakan strategi pelayanan yang efisien.

Dinas Kependudukan dan Pencatatan Sipil Kabupaten Tolitoli merupakan salah satu pelaksana pelayanan administrasi publik di wilayah Sulawesi Tengah. Pelayanan Kependudukan ini meliputi pendaftaran Penduduk dan Pencatatan Sipil. Pendaftaran peduduk meliputi pembuatan Kartu Keluarga (KK), Kartu Tanda Penduduk Elektronik (eKTP). Salah satu pelaksana pelayanan publik, Dinas Kependudukan dan Pencatatan Sipil Kabupaten Tolitoli juga dituntut untuk memberikan pelayanan yang berkualitas sesuai dengan harapan dan keinginan masyarakat Tolitoli. Kualitas pelayanan ini diukur menggunakan 5 dimensi kualitas pelayanan publik yaitu, (tangible) bukti fisik, (reliability) kehandalan, (responsiveness) daya tanggap, (assurance) jaminan, dan (empathy) empati.

Berdasarkan hasil penelitian yang dilakukan oleh peneliti pada Dinas Kependudukan dan Pencatatan Sipil Kabupaten Tolitoli, terdapat beberapa permasalahan terkait dengan lima dimensi kualitas pelayanan tersebut.

Indikator pertama tangible, seperti kelengkapan sarana dan prasarana pelayanan di Dinas Kependudukan dan Pencatatan Sipil Kabupaten Tolitoli masih kurang, sepertitidak ada papan informasi yang disediakan untuk mempermudah masyarakat dalam melihat persyaratan suatu layanan, Kurangnya pendingin ruangan (kipas angin atau air conditioner) dalam ruang pelayanan. Hal ini menjadikan masyarakat yang mengantri merasa kurang nyaman dengan adanya masyarakat yang mengantri setiap harinya. Adanya penumpukan berkas diruang pelayanan. Selain itu, tempat duduk yang ada di ruang tunggu dinilai masih kurang dilihat dari adanya beberapa masyarakat yang berdiri saat menunggu antrian.

Indikator kedua ke-dua terkait dengan aspek reliability atau kehandalan, yaitu belum memuaskannya kualitas pelayanan Dinas Kependudukan dan Pencatatan Sipil Kabupaten Tolitoli dilihat dari adanya keluhan dari masyarakat tentang proses pembuatan produk layanan, seperti Akta Kelahiran, Kartu Keluarga (KK), dan Kartu Tanda Penduduk (KTP). Permasalahan lain yang ditemui yaitu masih adanya masyarakat yang belum mengetahui persyaratan apa saja yang harus dibawa untuk mengajukan permohonan pembuatan produk layanan. Tidak optimalnya informasi yang diterima oleh masyarakat 
Gafar. Kualitas Pelayanan Publik di Dinas Kependudukan ...

tentang produk, syarat, dan lama pembuatannya. Seharusnya disetiap ruang pelayanan dicantumkan sturktur persyaratan produk seperti Kartu Tanda Penduduk, (KTP), Kartu Keluarga (KK) dan Akte Kelahiran. Hal tersebut memperlihatkan bahwa petugas Dinas Kependudukan dan Pencatatan Sipil belum memberikan informasi yang jelas dan menyeluruh kepada masyarakat Tolitoli.

Indikator ke-tiga berkaitan dengan aspek responsiveness (daya tanggap), yaitu pegawai Dinas Kependudukan dan Pencatatan Sipil Kabupaten Tolitoli dinilai sudah tanggap dalam memberikan pelayanan kepada masyarakat seperti pada saat masyarakat menanyakan persyaratan sebuah produk layanan seperti KTP (Kartu Tanda Penduduk). Pegawai merespon masyarakat dengan baik.

Indikator ke-empat terkait dengan aspek assurance atau jaminan. Jaminan yang dimaksud meliputi jaminan keamanan. Pegawai Dinas Kependudukan dan Pencatatan Sipil Kabupaten Tolitoli sudah memberikan jaminan keamanan kepada masyarakat. pemerintah sudah menyediakan lapangan parkir untuk kendaraan masyarakat, pegawai mampu memberikan rasa aman kepada masyarakat dengan cara meyakinkan masyarakat bahwa setiap pelayanan yang di ajukan akan diselesaikan dengan baik.

Dari permasalahan yang telah sebutkan, diketahui bahwa Dinas Kependudukan Dan Pencatatan Sipil Kabupaten Tolitoli sudah memberikan pelayanan yang baik kepada masyarakat. namun masih ada beberapa indikator yang belum berjalan dengan baik.

\section{METODE}

Pendekatan yang digunakan dalam penelitian ini adalah metode penelitian deskripitif dengan pendekatan kualitatif. (Sugiyono 2015:15) menjelaskan Metode deskriptif kualitatif adalah metode penelitian yang berlandaskan pada filsafat positivisme, digunakan untuk meneliti pada kondisi objek yang alamiah (sebagai lawannya adalah eksprimen ) dimana peneliti sebagai instrumen kunci, pengambilan sampel data dilakukan dengan cara purpusive dan snowball, tehnik penggabungan dengan trigulasi (gabungan), analisis data bersifat induktif/kualitatif, dan hasil penelitian kualitatif lebih menekankan makna dari pada generalisasi.
Tipe penelitian ini berusaha mendeskripsikan gambaran yang senyatanya dari fenomena yang terjadi pada tingkat Pelayanan Aparat pada Masyarakat, khusus di Kabupaten Tolitoli. Pendekatan dengan metode deskriptif kualitatif digunakan untuk meneliti pada kondisi obyek yang alamiah, dimana peneliti adalah instrumen kunci.

Lokasi penelitian adalah tempat dimana calon peneliti akan melakukan penelitian, yaitu Dinas Kependudukan dan Pencatatan Sipil Kabupaten Tolitoli. Pemilihan lokasi ini dilakukan sejak dilakukannya observasi awal.

Penelitian ini dilaksanakan selama 2 bulan yaitu dari April s/d Mei. terhitung sejak dikeluarkannya surat izin penelitian dari Fakultas Ilmu Sosial Dan Ilmu Politik Universitas Madako Tolitoli.

Informan dalam penelitian ini adalah orang-orang yang dapat memberikan informasi dalam sebuah penelitian yaitu Sekertaris Dinas Kependudukan dan Pencatatan Sipil Kabupaten Tolitoli sebagai informan kunci dan masyarakat sebagai pembanding.

Definisi operasional pada hakikatnya bertujuan memudahkan pengukuran indikatorindikator atau aspek penelitian, konsep penelitian yang digunakan harus dioperasionalkan kedalam sebuah definisi operasional yang sesuai dengan permasalahan penelitian. dengan kata lain definisi operasional adalah unsur penelitian yang memberitahukan bagaimana cara mengukur suatu indikator/aspek. Oleh karena itu, konsepkonsep yang terkait dengan Kualitas Pelayanan ini perlu dioperasionalisasikan dengan berbagai aspek sesuai dengan teori yang digunakan.

1. Tangibles (bukti fisik) : meliputi fasilitas fisik, perlengkapan, pegawai sarana dan prasarana. seperti adanya computer untuk mengakses, disediakannya kursi untuk masyarakat yang memiliki keperluan.

2. Reliability (kehandalan) : merupakan kemampuan memberikan pelayanan sesuai yang dijanjikan terpercaya dan akurat, serta konsisten.

3. Responsiveness (daya tanggap) : yaitu sikap tanggap pegawai dalam memberikan pelayanan yang dibutuhkan masyarakat dan dapat menyelesaikan dengan cepat.

4. Assurence(jaminan) : yaitu berupa kemampuan karyawan untuk meyakinkan dan memberikan rasa kepercayaan terhadap janji yang telah dikemukanan kepada konsumen. 
5. Empathy (empati) : meliputi kemudahan dalam melakukan hubungan, komunikasi yang baik dan memahami kebutuhan pelanggan.

Proses pengumpulan data merupakan suatu hal yang penting dalam penelitian, menurut (sugiyono:2012) tehnik pengumpulan data adalah langkah yang paling utama dalam mendapatkan data. Maka peneliti akan mendapatkan data yang memenuhi standar yang ditetapkan. karena proses ini memerlukan strategi untuk mendapatkan data yang diperlukan. Keberhasilan penelitian sebagian besar tergantung pada teknik-teknik pengumpulan data yang digunakan. Pengumpulan data dalam penelitian ini dimaksudkan untuk memperoleh bahan- bahan, keterangan, kenyataan-kenyataan dan informasi yang dapat dipercaya karena berdasarkan.

1. WNI/ Warga Negara Indonesia

2. Berdomisili di Kabupaten Tolitoli (yang dibuktikan dengan Kartu Tanda Penduduk/KTP Atau Surat Keterangan Lainnya)

Dalam rangka mengumpulkan data dan informasi yang valid, akurat, dan relevan sehubungan dengan penelitian ini, maka peneliti akan melakukan serangkaian teknik pengumpulan data sebagai berikut

1) Observasi (pengamatan)

Observasi merupakan bagian yang sangat penting dalam penelitian kualitatif. Dengan observasi peneliti dapat mendokumentasikan dan merefleksi secara sistematis terhadap kegiatan dan interaksi subjek penelitian Burns, 1990 (Basrowi dan Suwandi 2008:93).

Observasi dalam penelitian ini meliputi kegiatan melihat dan mengamati secara langsung keadaan dilapangan menyangkut proses pemberian Pelayanan Publik Di Dinas Kependudukan dan Pencatatan Sipil Kabupaten Tolitoli.

2) Wawancara

Menurut(Riyanto 2010:82)Wawancara (interview) merupakan metode pengumpulan data yang menghendaki komunikasi langsung antara penyelidik dengan subjek atau responden. Wawancara adalah mentode pengambilan data dengan cara menanyakan sesuatu kepada seseorang yang menjadi informan atau responden.

3) Dokumentasi

Metode dokumentasi adalah pengambilan data yang di proses melalui dokumen-dokumen. Metode dokumentasi dipakai untuk mengumpulkan data dari sumber-sumber dokumen yang mendukung. (Harsono 2008:165) Teknik ini dilakukan untuk memperoleh data yang berupa dokumen atau arsip. Metode dokumentasi digunakan untuk melengkapi data yang diperoleh dari wawancara dan observasi.

Menurut Miles dan Huberman (Sugiyono 2014: 246-253) dalam Bukunya Memahami Penelitian Kualitatif bahwa aktifivitas dalam analisis data deskriptif kualitatif melalui tiga cara yaitu :

\section{1) Pengumpulan Data}

Pada tahap ini peneliti melakukan proses pengumpulan data dengan menggunakan teknik pengumpuian data yang telah ditentukan sejak awal. Proses pengumpulan data ini harus melibatkan sisi aktor (informan), aktivitas, latar, atau konteks terjadinya peristiwa. Sebagai "alat pengumpul data"peneliti harus pandaipandai mengelola waktu yang dimiliki, menampilkan diri, dan bergaul di tengahtengah masyarakat yang dijadikan subjek Penelitiannya.

2) Reduksi Data (Data Reduction)

Reduksi data merupakan data yang diperoleh dari lapangan jumlahnya cukup banyak, untuk itu perlu dicatat secara teliti dan rinci. Menurut Sugiyono semakin lama penelitian kelapangan, maka jumlah data akan semakin banyak, kompleks dan rumit untuk itu perlu dilakukan analisis data melalui reduksi data, Meredukasi berarti merangkum, memilih hal-hal yang pokok, mempokuskan pada hal-hal yang penting.

\section{3) Penyajian Data ( Data Display)}

Penyajian data adalah mendisplaykan data Menurut Sugiyono yang paling sering digunakan untuk menyajikan data dalam penelitian kualitatif adalah dengan teks yang bersifat naratif. Dengan penyajian data, maka akan mempermudah untuk memahami apa yang terjadi, merencanakan kerja selanjutnya berdasarkan apa yang telah dipahami.

4) Penarikan Kesimpulan atau verifikasi (Conclusion drawing)

Penarikan kesimpulan atau verifikasi dikakukan berdasarkan data yang telah disajikan, dan merupakan kegiatan pengungkapan akhir dari hasil penelitian masih perlu diuji kebenarannya, kekokohannya, dan 
Gafar. Kualitas Pelayanan Publik di Dinas Kependudukan ...

kesesuaian makna-makna yang muncul dari data.

\section{HASIL DAN PEMBAHASAN}

Setiap pelayanan akan menghasilkan beragam penilaian yang datang dari pihak yang dilayani atau pengguna layanan. Pelayanan yang baik tentunya akan memberikan penilaian yang baik pula dari para pelanggang, tatapi apabila pelayanan yang diberikan tidak memberikan kepuasan, misalnya terkait jangka waktu pelayanan yang tidak tepat maka akan menimbulkan kekecewaan pelanggang dan bisa memperburuk citra pemberi layanan. Untuk mengetahui kepuasan pelanggang dapat dilakukan dengan survei pelanggang yang didasarkan pada dimensi-dimensi yang dirancang para ahli yang dapat diadopsi, atau sebagai alat pemandu aparatur, menurut Zeithaml dkk (Hardianyah, 2011:46-47) kualitas pelayanan dapat diukur dengan menggunakan 5 dimensi yaitu: (Tangible) bukti fisik, (Reability) kehandalan, (Responsiviness) ketanggapan, (Assurance) Asuransi, (Empathy) empati.

1) Dimensi bukti Fisik (Tangible)

Menurut Assegaff, 2009 : 172 bahwa bukti fisik merupakan seberapa baik penampilan dan kemampuan sarana dan prasarana fisik harus dapat diandalkan.penampilan fisik pelayanan, pegawai ,dan komunikasi akan memberikan warna dalam pelayanan .tingkat kelengkapan akan berpengaruh pada pelayanan kepada masyarakat.dalam hal ini sejauh mana perusahaan memfasilitasi sarana dan prasarana sebagai upaya untuk memberikan kemudahan dalam pelayanan adalah hal yang tidak terpisahkan.

Kenyamanan tempat melakukan pelayanan. Kenyamanan yaitu lingkungan pelayanan harus tertib, teratur, disediakan ruang tunggu yang nyaman dengan menggunakan pendingin ruangan agar pengguna layanan nyaman dalam melakukan pelayanan, bersih, rapi, lingkungan yang indah dan sehat serta dillengkapi dengan fasilitas pendukung pelayanan.

Dari informan mengungkapkan mengenai dimensi Tangible atau bukti fisik yang berkaitan pada Dinas Kependudukan Dan Pencatatan Sipil Kabupaten Tolitoli Yaitu :

Berdasarkan hasil wawancara Peneliti dengan salah satu masyarakat di Dinas Kependudukan Dan Pencatatan Sipil Kabupaten Tolitoli ibu Iis Yulianti Mengatakan Bahwa :

"Dinas Kependudukan dan Pencatatan Sipil Kabupaten Tolitoli masih memiliki beberapa kekurangan dalam aspek sarana dan prasarananya seperti jumlah komputer yang kurang, ruangan pelayanan yang sempit, kursi yang disediakan jumlahnya sedikit."(wawancara Tanggal 11 April 2019)

Informan kunci mengatakan bahwa :

"saya selaku sekertaris Dinas Kependudukan dan Pencatatan Sipil Kabupaten Tolitoli selalu memberikan pengarahan kepada setiap anak-anak saya dalam menjalankan tugasnya. Namun melihat dari aspek sarana dan prasarana kita masih memiliki beberapa kendala seperti, komputer yang disediakan jumlahnya terbatas hanya 17 buah komputer bahkan ada beberapa diantaranya sudah rusak atau tidak layak pakai. Hal ini tidak sesuai dengan banyaknya masyarakat yang datang kemari setiap harinya. Tapi kami selalu mengusahakan bagaimana agar kendalakendala yang kami hadapi dapat diselesaikan secepatnya." (Wawancara Tanggal 30 April 2019).

Peneliti menyimpulkan pada indikator tangible atau bukti fisik. Dinas Kependudukan dan Pencatatan Sipil Kabupaten Tolitoli masih memiliki kekurangan terkait dengan sarana dan prasarananya, seperti kondisi ruangan yang sempit, kurangnya kursi yang disediakan dan pendingin ruangan yang kurang. Hal tersebut berdampak buruk terhadap pegawai dan masyarakat sebagai pengguna layanan.

2) Dimensi Kehandalan (Reliability)

$$
\text { Menurut Assegaff,2009 : }
$$
mengatakan bahwa kehandalan merupakan suatu kemampuan dalam memenuhi janji (tepat waktu,konsisten dan kecepatan dalam pelayanan). tingkat konpetensi perusahaan juga dapat dilihat dari sini sejauh mana tingkat kemampuan perusahaan dapat ditunjukan.kehandalan berkaitan dengan kemungkinan suatu pegawai melaksanakan fungsinya secara berhasil.

Keahlian petugas menggunakan alat 
bantu pelayanan. Keahlian berarti sudah lebih mampu dalam menguasai. Keahlian merupakan sesuatu yang harus dimiliki pegawai dalam proses pelayanan agar pelayanan berjalan dengan lancar. Selanjutnya penulis mewawancarai informan tentang Dimensi Reability (Kehandalan) yaitu sebagai berikut :

Berdasarkan hasil wawancara Peneliti dengan salah satu masyarakat di Dinas Kependudukan Dan Pencatatan Sipil Kabupaten Tolitoli ibu Iis Yulianti mengatakan bahwa;

"terkadang pegawai yang bersangkutan tidak ada di tempat sehingga dapat menghambat proses pelayanan dan waktu pembuatan produk layanan sering mengalami keterlambatan atau tidak sesuai dengan waktu yang sudah ditentukan" (wawancara Tanggal 11 April 2019)

Informan Kunci mengatakan:

"Mengenai ketepatan pegawai Kami sudah melakukan proses pelayanan yang sesuai dengan ketentuan yang sudah di tetapkan. Hanya saja biasanya kami mengalami kendala seperti adanya gangguan jaringan, lampu padam hal tersebut dapat menggangu jalannya sebuah pelayanan." (wawancara pada Tanggal 17 April 2019)

Dari beberapa hasil wawancara diatas menunjukkan bahwa proses kegiatan pelayanan kepada masyarakat masih mengalami hambatan seperti ketepatan pegawai dalam menyelesaikan keperluan masyarakat, terkadang waktu yang dibutuhkan tidak sesuai dengan apa yang sudah disepakati dikarenakan adanya suatu permasalahan berupa kehabisan belangko sehingga dapat menghambat proses pelayanan.

3) Dimensi Daya Tanggap (Responsiviness)

Jaminan dan kepastian merupakan pengetahuan dan keramahan pegawai serta kemampuan melaksanakan tugas secara spontan yang dapat menjamin kerja yang baik, sehingga menimbulkan kepercayaan dan keyakinan masyarakat.Tingkat pengetahuan mereka akan menunjukan tingkat kepercayaan bagi masyarakat,sikap ramah, sopan, bersahabat adalah menunjukan adanya perhatian pada masyarakat. Jaminan tepat waktu sangat diperlukan oleh pengguna layanan agar pengguna layanan merasa yakin dengan waktu yang diberikan oleh penyedia layanan.Jaminan Kepastian biaya dalam pelayanan. Jaminan kepastian biaya biasanya ada pada standar pelayanan publik masing- masing penyedia pelayanan.

Hasil wawancara dengan salah satu tokoh masyarakat yaitu bapak Yusran beliau berpendapat bahwa;

"Sikap pegawai dalam memberikan pelayanan kepada masyarakat sudah baik. Terlihat dari caranya memberikan pemahaman kepada masyarakat, yang kurang faham akan persyaratan suatu layanan." (wawancara pada Tanggal 08 April 2019)

Informan kunci mengatakan bahwa:

"jika dilihat dari aspek responsiviness atau daya tanggap. pelayanan yang diberikan oleh pegawai itu sudah cepat dalam memberikan pelayanan pegawai-pegawai dituntut untuk menyelesaikan suatu produk entah itu pembuatan Kartu Keluarga (KK), Kartu Tanda Penduduk (KTP) dan lain-lainya di karenakan dalam pembuatan suatu produk itu waktu kerjanya selama 14 hari sejak dilengkapinya berkas dari masyarakat. Pegawai disini cukup tanggap dalam artian mengerti dengan kemamuan masyarakat". (Wawancara Tanggal 30 April 2019).

Penulis menyimpulkan bahwa dari dimensi responsiv kepada masyarakat sudah dilakukan sebagaimana mestinya. Sesuai dengan Standar Operasional Prosedur yang ada pada Dinas Kependudukan dan Pencatatan Sipil Kabupaten Tolitoli.

4) Dimensi Jaminan (Assurance) Jaminan dan kepastian merupakan pengetahuan dan keramahan pegawai serta kemampuan melaksanakan tugas secara spontan yang dapat menjamin kerja yang baik,sehingga menimbulkan kepercayaan dan keyakinan masyarakat. Tingkat pengetahuan mereka akan menunjukan tingkat kepercayaan bagi masyarakat,sikap ramah, sopan, bersahabat adalah menunjukan adanya perhatian pada masyarakat. Jaminan tepat waktu sangat diperlukan oleh pengguna layanan agar pengguna layanan merasa yakin dengan waktu yang diberikan oleh penyedia layanan. Jaminan Kepastian biaya dalam pelayanan. Jaminan kepastian biaya biasanya ada pada standar pelayanan publik masing-masing penyedia pelayanan.

Berdasarkan hasil wawancara yang dilakukan oleh peneliti kepada salah satu tokoh masyarakat yaitu Ibu Iis Yulianti mengatakan bahwa;

"Saya melihat pelayanan yang diberikan oleh 
Gafar. Kualitas Pelayanan Publik di Dinas Kependudukan ...

pegawai pemerintah di Dinas Kependudukan Dan Pencatatan Sipil Kabupaten Tolitoli sudah baik dan mampu menyelesaikan sebuah keperluan masyarakat, seperti pembuatan KTP, perpindahan penduduk dan pembuatan kartu keluarga dan memberikan jaminan keamanan berupa penyediaan tempat parkir untuk setiap kendaraan."(wawancara pada Tanggal 11 April 2019)

Informan kunci berpendapat:

"Pelayanan yang kami berikan sudah berdasarkan dengan (SOP) standar operasional pelayanan. Jadi saya merasa kemampuan pegawai dalam memberikan pelayanan sudah baik dan kita disini akan bertanggung jawab sepenuhnya terhadap pelayanan publik." (wawancara pada Tanggal 26 April 2019)

Penulis menyimpulkan bahwa dari sisi assurance atau jaminan Pegawai memberikan rasa aman kepada masyarakat dengan meyakinkan masyarakat untuk menyelesaikan setiap pelayanan yang di berikan. Sesuai dengan Standar Operasional Prosedur yang ada pada Dinas Kependudukan dan Pencatatan Sipil Kabupaten Tolitoli.

5) Dimensi Empati (Emphaty)

Empati adalah memberikan perhatian dan mampu berkomunikasi dengan baik dan memahami kebutuhan setiap pelanggang Pengguna layanan merupakan prioritas dalam proses pelayanan. Sebagai pegawai pelayanan sebaiknya mendahulukan kepentingan pengguna layanan dari pada kepentingan yang bersifat pribadi.Dalam melayani pengguna layanan, pegawai tidak boleh membedabedakan pengguna layanan yang akan mengurus keperluannya di kantor pelayanan. Semua harus dilayani sesuai dengan nomor antrian yang disediakan.

Hasil wawancara dengan salah satu masyarakat Ibu Iis Yulianti beliau berpendapat bahwa;

".pegawai selalu mengutamakan kepentingan umum Pegawai sudah memberikan arah dan petunjuk tentang mekanisme pelayanan kepada masyarakat yang masih bingung kemudian dari cara berkomunikasinya mampu menjelaskan secara rinci hal itu saya rasakan pada saat saya mengurus persyaratan pindah domisili saya diberikan pemahaman ." (wawancara pada Tanggal 11 April 2019)
Informan kunci mengatakan bahwa : "Kami selalu memberikan kemudahan kepada setiap masyarakat entah itu pembuatan Kartu Tanda Penduduk(KTP), Kartu Keluarga (KK), ataupun Akte Kelahiran dan kami menyadari bahwa hubungan pegawai dengan pegawai lainnya dilini pemerintahan terjalin dengan baik semunya saling mensuport saling membantu satu sama lain dalam menyelesaikan suatu pekerjaan dan kami selalu mengutamakan kepentingan publik . (Wawancara Tanggal 30 April 2019)

Penulis menyimpulkan bahwa pelayanan yang diberikan pegawai kepada masyarakat sudah berjalan dengan baik. Pegawai tidak membeda-bedakan masyarakat sebagai pengguna layanan, sikap dan tanggung jawab pegawai sudah diterapkan dengan baik. Dalam hal ini masyarakat sebagai pengguna layanan mendapat hak yang sama dalam proses pelayanan.

\section{SIMPULAN DAN SARAN}

Berdasarkan hasil penelitian dan uraian pembahasan tentang kualitas pelayanan publik di Dinas Kependudukan dan Pencatatan Sipil Kabupaten Tolitoli, di peroleh kesimpulan sebagai berikut: Kualitas pelayanan publik Dinas Kependudukan dan Pencatatan Sipil Kabupaten Tolitoli dapat dinilai dari lima dimensi yaitu, Tangible, Reliability, Responsiviness, Assurance, dan Empathy. (a) Dimensi Tangible, Berdasarkan hasil penelitian yang dilakukan terkait dengan bukti fisik, fasilitas pendukung pelayanan di Dinas Kependudukan dan Pencatatan Sipil Kabupaten Tolitoli belum memadai dan memuaskan masyarakat. hal ini dikarenakan kurangnya fasilitas yang di sediakan untuk perlengkapan penunjang pelayanan; (b) Dimensi Realibility atau kehandalan. Dinas Kependudukan dan Pencatatan Sipil Kabupaten Tolitoli masih kurang handal dalam menyelesaikan produk layanan. Terkadang waktu yang ditentukan dalam menyelesaikan proses layanan tidak sesuai dengan batas waktu yang sudah ditetapkan; (c) Dimensi responsiviness, Di ketahui bahwa pegawai Dinas Kependudukan dan Pencatatan Sipil Kabupaten Tolitoli melayani masyarakat dengan baik. Yaitu pegawai merespon hal-hal yang ditanyakan masyarakat dan memberi pengarahan terkait dengan pertanyaan yang di tanyakan 
masyarakat. pegawai melayani dengan ramah dan sopan; (f) Dimensi Assurance, Dapat ditarik kesimpulan bahwa Dinas Kependudukan dan Pencatatan Sipil Kabupaten Tolitoli telah memberikan jaminan kemudahan layanan dan jaminan keamanan kepada masyarakat yang mengajukan permohonan layanan. Hanya saja saja terkadang waktu penyelesaian layanannya tidak sesuai dengan waktu yang ditentukan; (g) Dimensi Empathy, Dinas Kependudukan dan Pencatatan Sipil Kabupaten Tolitoli telah memberikan pelayanan yang baik kepada masyarakat. hal ini tercapai karena pegawai yang melayani masyarakat memiliki sikap yang ramah dalam menghadapi permintaan, kritik dan saran yang diberikan oleh masyarakat.

Untuk meningkatkan kualitas pelayanan publik di Dinas Kependudukan dan Pencatatan Sipil Kabupaten Tolitoli peneliti memberi saran yaitu, Dinas Kependudukan dan Pencatatan Sipil Kabupaten Tolitoli sebaiknya menambah fasilitas pendukung layanan seperti sarana. Agar masyarakat merasa nyaman pada saat berada didalam ruangan pelayanan dan hendaknya pegawai diberikan pendidikan dan pelatihan dalam menjalankan tugas dan tanggung jawab demi tercapainya kualitas pelayanan publik. Agar masyarakat dapat merasa puas dengan pelayanan yang diberikan.

\section{DAFTAR RUJUKAN}

Assegaf, F., 2009 Proses produksi Bioetanol Bonggol Pisang (Musa Paradisiacal) menggunakan metode Hidrolis Asam Enzimatis. Universitas Jenderal Soedirman.

Basrowi, dan Suwandi, 2008, Memahami Penelitian Kualitatif, Jakarta: Rineka Cipta.

Hardiansyah .2011. Kualitas Pelayanan Publik. Yogyakarta: Gava Media

Harsono, 2008. Pengelolaan Perguruan Tinggi.Yogyakarta: Pustaka Pelajar

Miles dan Huberman, 2009. CetakanI, Analisis data Kualitatif: IndonesiaUI Pres.
Riyanto. 2009 Pegembangan Aplikasi Sistem Informasi Geografis Berbasis Dekstop dan Web. Gava Media. Yogyakarta.

Sugiyono. 2014. Metode PenelitianPendidikan
Pendekatan Kuantitatif, Kualitatif, dan $R \& D$. Bandung: Alfabeta

Undang-Undang No. 24 Tahun 2013, TentangAdministrasi Kependudukan. 